\title{
衛星伝送画像と温度測定による崩壊斜面の侵食に関する解析* 一春木川の破砕粘板岩地帯を例に-
}

Analysis of erosion on the collapsed slope by using the satellite-transmitted pictures and temperature data - At fractured slates in the Haruki River -

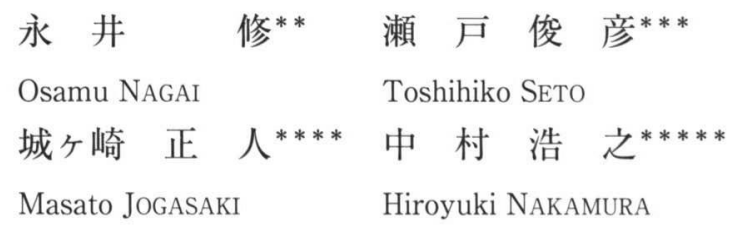

\begin{abstract}
In Mar., 1998, Fujikawa Sabo Works Office, Ministry of Construction set up a remote surveillance camera at the upper reach of the Haruki River to transmit pictures of the collapsed slope to the office by satellite telecommunication for the purpose of observation through a year. The interrelations between occurrence time of rock fall due to the freeze and thaw, and air temperature have become clear by analyzing the pictures of the collapsed slope and fluctuation of air temperature at the crushed slates in the Haruki River. The pictures transmitted from the observation site show that fall of rock fragments from the collapsed slope began in the end of February triggered by a rise in air temperature. And according to the analysis of the transmitted pictures and a survey of the talus cones at the observation site, eroded depth at the collapsed slope in winter season of 1999 is $4.9 \mathrm{~cm}$.
\end{abstract}

キーワード : picture transmitting system*, freeze and thaw*, fractured slates*

\section{1.はじめに}

山梨県南西部に位置する富士川水系早川右支春木川は 建設省関東地方建設局富士川砂防工事事務所（以下富士 川砂防工事事務所と呼ぶ）管内にあり，春木川左支大春 木沢の源頭部には七面山大崩れを抱えて現在も大量の土 砂を生産し続けている重点監視河川である。春木川にお ける既往の生産土砂量調査（例えば，富士川砂防工事事 務所, 1985a，1985b）は, 源頭部での土砂生産の多く は冬季の凍結・融解によるものと報告している。これら の報告は過去の空中写真の変化や夏と秋の現場踏查によ る崩壊斜面の変化を基にして, 夏 (雨季前) から秋まで の変化量を豪雨による夏季の土砂生産量とし, 秋から翌 年の夏までの変化量は凍結・融解による土砂生産量であ ると推定している。本来, 雨季前と秋に調査を行う目的

* 一部は平成11年度地すべり学会研究発表会で発表した。

$* *$ 東京農工大学大学院連合農学研究科博士課程

$* * *$ 建設省関東地方建設局富士川砂防工事事務所 (元)

$* * * *$ 建設省関東地方建設局河川計画課（元）

$* * * * *$ 東京農工大学大学院
は, 夏季の豪雨（台風や梅雨）による崩壊斜面の変化や 河床変動を捉えることによって雨量と土砂生産・移動の 関係を明らかにしょうというものであって，冬季の土砂 生産量は二次的に解析されたものである。したがって, 秋から翌年の夏までという長期間に, 崩壊がいつ, どの ように発生したのかという解析はこれまで十分には行わ れていない。今回, 冬季の土砂生産量が夏季のそれを上 回る春木川（富士川砂防工事事務所, 1985a）において, 崩壊斜面の変化を画像で捉え，同時に気温・岩盤の温度 変化を測定することによって, 冬季の凍結・融解による 土砂生産量を時系列で解析した。

春木川流域のように大規模崩壊地を源頭部にもつ山地 河川での崩壊斜面の観測には, 落石や予期せぬ多くの危 険に遭遇することが考えられる。特に冬季の観測は, 降 雪や路面凍結の影響でアクセスそのものが危険に満ちて おり，現場に到達するまでに多くの困難を伴う。今回採 用した崩壊斜面の監視システムには，このような冬季の 厳しい気象条件下でも遠隔操作で定期的に崩壊斜面の監 視が可能なこと, またメンテナンスフリーの気象観測機 器を併用することによって崩落の解析にも利用できると 
いった利点がある。

富士川砂防工事事務所では，1998年 3 月から春木川上 流大春木沢に大春木ダム上流の監視を兼ねて衛星通信に よる画像伝送システムを使った崩壊斜面の監視カメラを 設置した。この画像伝送システムによって伝送された崩 壊斜面の画像と, 同地点における気温と岩盤温度の変化 を観測することによって, 凍結・融解による崩落の発生

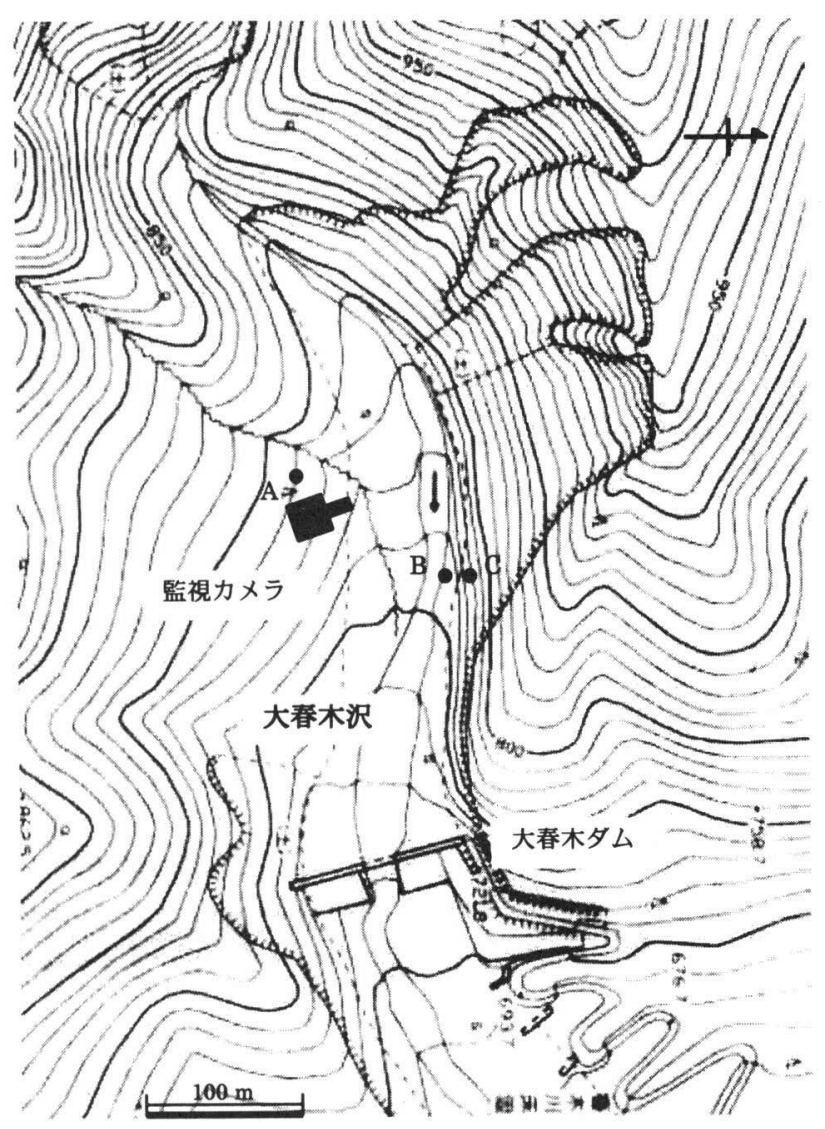

図-1 観測崩壊斜面付近の地形図

A，Bは気温観測点，Cは岩盤温度観測点)

A

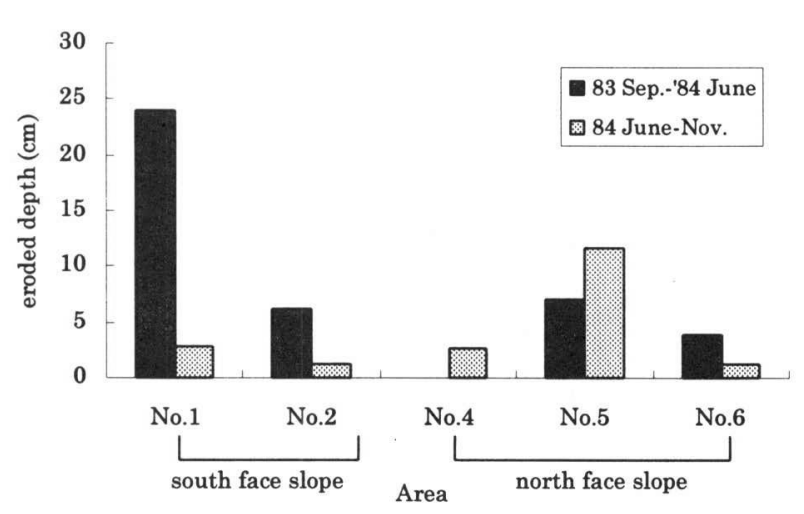

図一２岩盤斜面の侵食量

$\mathrm{A}$ ：斜面の方位別侵食量 $\mathrm{B}$ ：岩種別（砂岩·粘板岩互層, 砂岩, 粘板岩) 侵食量 七面山大崩れ主崩壊地部における地上写真測量成果に基づく侵食量 (春木川生産土砂量調查報告：富士川砂防工事事務所，1985b）
時期と気温の関係を明らかにすることができた。採用し たシステムには, 低温に対応する十分な電力の確保や, 解析に必要な画像の解像度の問題など検討すべき点が多 くあるが，それらを今後の課題として，システムの概要 と得られたデータの解析結果を報告する。

\section{2. 観測地の概況}

画像伝送システムと気温観測機器を設置した場所は, 春木川左支大春木沢にある大春木夕゙ムの上流堆積域であ る（図-1, 写真 -1 )。大春木沢の流域面積は $2.2 \mathrm{~km}^{2}$, 最高点は $1982 \mathrm{~m}$ の七面山である。源頭部の七面山大崩れ から大春木沢の下流部に至るまで, 崩壊斜面の多くは南 向きであり,この傾向は瀬戸川層全域に共通している(永 井, 1998)。図-2 は富士川砂防工事事務所が行った七 面山大崩れにおける地上写真解析による侵食量調査結果 である（富士川砂防工事事務所，1985b）。これによる と, 冬季に南向き斜面での侵食の進行が顕著であり, 岩 種によって侵食量に大きな差がある。このような理由か ら, 観測対象とした崩壊斜面を南向き斜面とした。観測

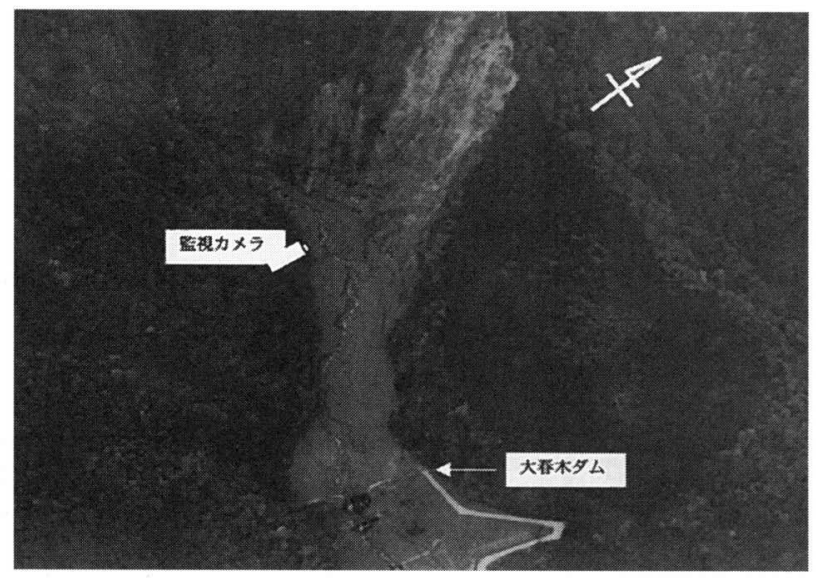

写真－1大春木沢の観測斜面（1998年11月空撮）

B

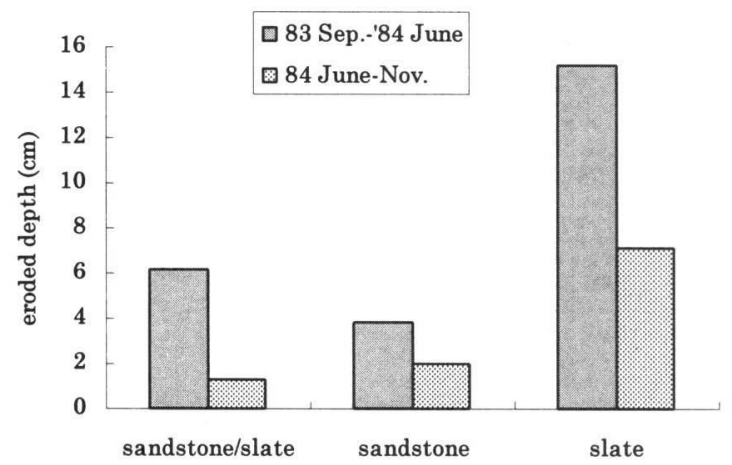


斜面は古第三紀に生成された瀬戸川層群春木川累層に属 乙（山梨県地質図編纂委員会，1970），砂岩と千枚岩質 粘板岩の互層で千枚岩質粘板岩が卓越している。また地 層は西に30度傾斜している。観測斜面の標高は頂部で 960 $\mathrm{m}$, 脚部で $770 \mathrm{~m}$ 地点に位置し, 斜度は平均 52 度, 斜面 積は $46,000 \mathrm{~m}^{2}$ である。崩壊斜面は現在も崩落が続い ており植生はほとんど見られず，夏季に僅かに草本類が 侵入する程度である。

\section{3. 画像伝送システムと温度観測の概要}

観測地では設置した時点（現在は光ファイバーケーブ ルが敷設されている）で電源と一般電話回線が利用でき なかったことと, 冬季は凍結などアクセスに危険が伴い メンテナンスフリーに対応できることが要求されること から, 画像伝送システムの電源はソーラー発電に頼り, 伝送は衛星通信を経由した電話回線を使用した。システ ムのステーションは観測地と工事事務所の 2 所からな り，その概要を図ー 3 に示す。崩壊斜面の観測は，1998 年 3 月から 2000 年 4 月まで連続して行った。画像の取り こみは, 撮影可能な露出が得られる時間帯で気温の最も

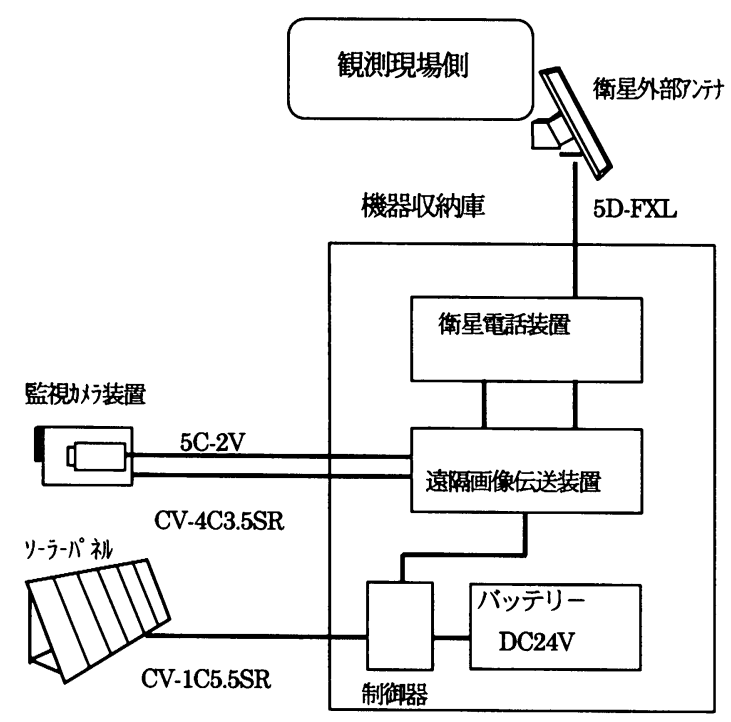

低い午前 7 時と最も気温の高くなると思われる午後 1 時 の 2 回とした。崩壊斜面の観測と並行した同地点におけ る気温と岩盤温度観測は，1998年が既に凍結・融解時期 を過きていたため，翌年の1999年および2000年の冬季に 実施した。

\section{1 画像伝送システムの構成と特徴}

観測地点でのシステム構成はバッテリー, 遠隔画像伝 送装置, 衛星携帯電話の入ったハウジングボックス, 監 視カメラの入ったカメラハウジングボックス, ソーラー パネル，外部アンテナの 4 つに分かれる。一方，富士川 砂防工事事務所側のシステム構成は遠隔画像受信装置, 専用電話回線，画像保存用のパソコンである。

システムを構成している機器類の仕様を表一 1 に示す。 また，システムの特徴は次のとおりである。

(1) $\mathrm{CCD}^{*}$ カメテて取りこまれる画像はリアルタイムで 遠隔地である工事事務所で確認できる。（実際には観 測地の発電能力から, 事前に午前 7 時と午後 1 時の 2 回画像伝送に設定, ${ }^{*} \mathrm{CCD}$ : charge coupled device, ビデオカメラに使用されている方式）

（2）現場で取りこまれた画像は，着信と同時に事務所で

図－3 崩壊斜面画像伝送システム概略図

表ー1 画像伝送システムの主な機器の仕様

遠隔画像伝送装置（伝送/受信）

\begin{tabular}{|c|c|c|c|c|}
\hline 品番 & 電源/消費電力 & 通信方式 & 画像 & 機能 \\
\hline GG-20JFA & $\begin{array}{l}\text { AC } 100 \mathrm{~V} \\
50 / 60 \mathrm{~Hz} \\
15 \mathrm{~W}\end{array}$ & \begin{tabular}{l|} 
一般電話回線使用 \\
通信速度 \\
$14000 / 9600 / 4800 / 2400 \mathrm{bps}$ \\
V.32bis/V.32/V22bis/V.21 \\
(全2 重)
\end{tabular} & $\begin{array}{l}\text { カラー静止画像 } \\
\text { JPEG 方式 } \\
\text { 画質 } \\
320 \times 240 \sim 640 \times 480\end{array}$ & $\begin{array}{l}\text { 画像記録: 端末センサ検知に連動して前後 } 24 \text { 画 } \\
\text { 面の画像を記録 } \\
\text { 通信機能: :リアルタイム画像通信可能/操作機の要 } \\
\text { 求により記録画像送信可能/端末機のテレンコン出 } \\
\text { カに接続した機器の ON/OFF を設定 }\end{array}$ \\
\hline \multicolumn{5}{|c|}{ 監視カメラ } \\
\hline 品番 & 電源/消費電力 & \multicolumn{2}{|l|}{ 画像 } & 機能 \\
\hline CCD-400 & $\begin{array}{l}\mathrm{DC} 12 \mathrm{~V} \\
4.0 \mathrm{~W}\end{array}$ & \multicolumn{2}{|c|}{$\begin{array}{l}\text { 素子 : 1/4インチ、インターライン転送方式 CCD } \\
\text { 有効画素数 : } 768 \times 494 \text { (38 万画素) }\end{array}$} & $\begin{array}{l}\text { レンズ : } 14 \text { 倍ズームレンズ (オート/マニュアル) } \\
\text { フォーカス : オート/OFF/至近/遠方/ダイレクト } \\
\text { ホワイトバランス : オート } \\
\text { シャッタースピード : } 1 / 60-1 / 10000\end{array}$ \\
\hline
\end{tabular}


既存のパソコンに保存される。

(3) 画像伝送は，衛星通信を経由した電話回線によるデ ジタル方式（JPEG圧縮／伸張方式, 圧縮率1/20）を 採用した。

(4) カメラハウジングにはデフロスター， ワイパーを装 備して雨天や低温に対応しており，事務所から遠隔制 御可能である。なお，デフロスターは自動制御である。

(5) ソーラー電源は蓄電池に電気を貯え，10日間日照が ない状態でも操作可能である。

(6) 画像の取り込みは, タイマーで任意の時間帯に電源 を $\mathrm{ON} / \mathrm{OFF}$ 設定し，自動的に発信する。

我

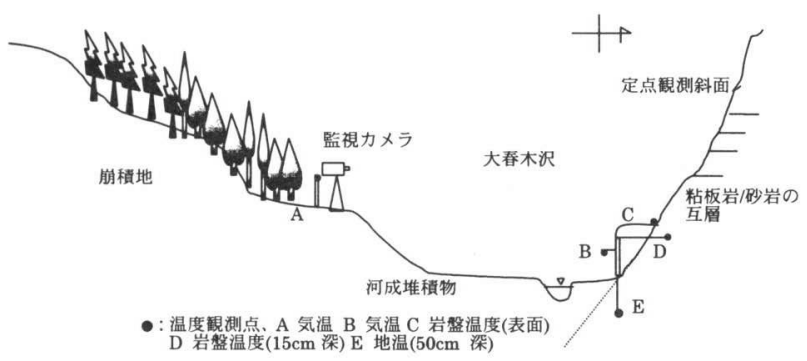

図-4 定点観測斜面周辺の地形断面概略図

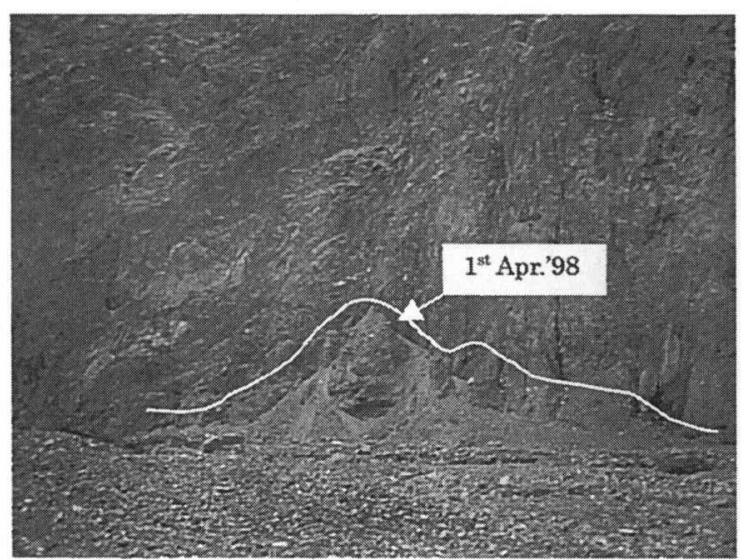

A 1997 年 12 月 22 日

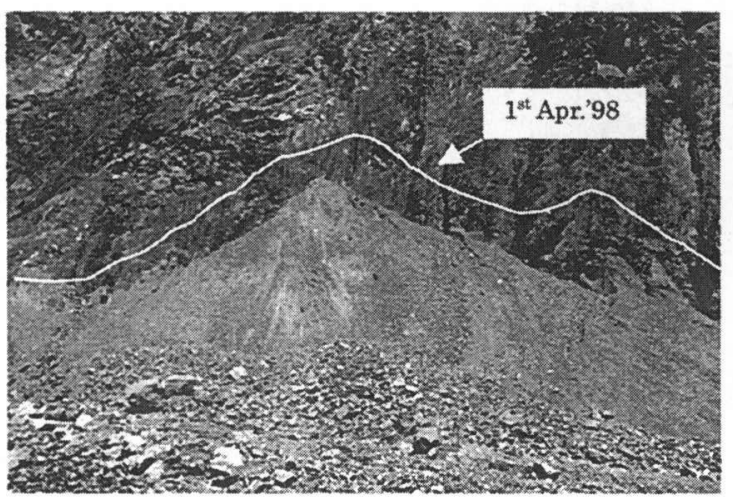

C 1998 年 8 月 13 日

\section{2 気温と岩盤温度の観測}

気温観測は，熱電対センサーと 6 チャンネル観測可能 なロガー（ユニパルス製，U Logger L822）を 2 個用い, 一つは崩壊斜面の岩盤近くに，もう一つは斜面から $80 \mathrm{~m}$ 離れた対岸に設置した（図－1，4）。岩盤近くに設置 したロガーで岩盤表面の温度，岩盤表面から深さ $15 \mathrm{~cm}$ での岩盤温度，崩壊斜面下に堆積した崩積土の地表から 深さ $50 \mathrm{~cm}$ での地温, 斜面から $1 \mathrm{~m}$ 離れた地点での気温 を 1 時間毎に記録した（図－4）。また，崩壊斜面から 80m離れた対岸に設置したロガーで気温を同じく 1 時間 毎に記録した。観測期間は冬季 1 月から 3 月末までとし た。

\section{4. 観測結果}

\section{1 崩壊斜面の経時的変化}

崩壊斜面の画像の取り込みは1998年 3 月から開始した が，それ以前に撮影した崩壊斜面の写真も含めて1997年 12月から1999年 4 月までの崩壊斜面の変化を見てみる。 写真 -2 Aは 1997 年12月 22 日の崩壊斜面である。この年 の $1 \sim 4$ 月に崩壊斜面下に形成された崖錘は 6 月 20 日に 記録した日降雨量 $129 \mathrm{~mm}$ に伴う出水によって侵食され たが，わずかに崖鍾形を留めている。また崩壊斜面から

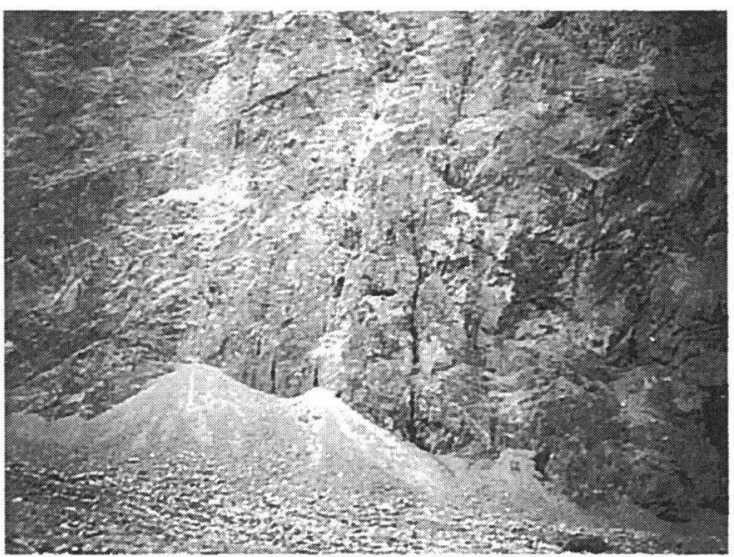

B 1998 年 4 月 1 日

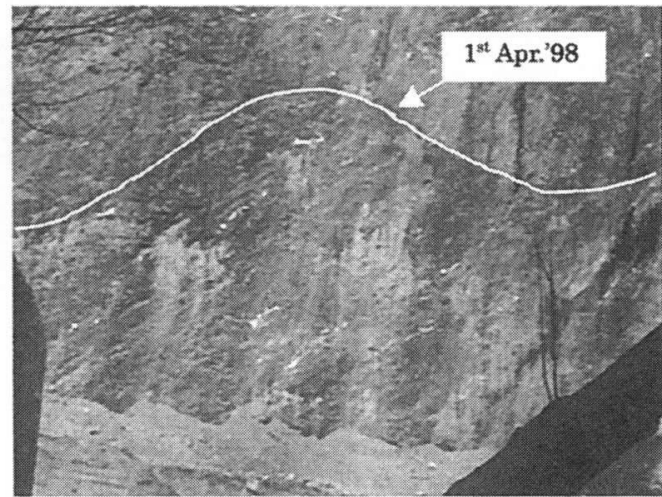

D 1998 年 11 月 16 日

写真一 2 観測崩壊斜面の変化

(AとBの崖錘の体積の差を1998年冬季の崩壊量として計算。Cは出水前の崖錘。Dは出水後崖錘が消失した斜面。河床 が大きく低下した。) 
の湧水は砂岩層には見られず，脚部の粘板岩層にわずか に認められる。写真 -2 Bは1998年 4 月 1 日における崩 壊斜面下の崖錘の状況であり, 冬季に大量の崩落が発生 し崖錘が大きく成長している。崩壊斜面上の湧水は, 主 に粘板岩層の層理面あるいは擘開部に集中し，前年の 12 月より増えている。地上写真 (写真 $-2 \mathrm{~A}, 2 \mathrm{~B}$ ) 解析 と光波測量によって崩壊斜面における1997年12月から 1998年 3 月までの侵食量を求めた。計算手順は次のとお りである。

(1) 写真解析と崖錘の実測から両時期における崖錘の底 辺の面積と高さを求め, 次式より冬季の土砂生産量を 推定する。

$$
Q=\frac{\left(a_{1} \cdot h_{1}\right)-\left(a_{2} \cdot h_{2}\right)}{3}
$$

ここで, $Q$ : 土砂生産量 $\left(\mathrm{m}^{3}\right), a_{1}, a_{2}$ : 両時期の崖 錘の底面積 $\left(\mathrm{m}^{2}\right), h_{1}, h_{2}$ : 画時期の崖錘の高さ $(\mathrm{m})$

(2) 採取した崩壊土砂を炬乾燥し崩壊土砂の乾燥密度を, また土粒子試験で崩壊した岩盤の土粒子密度を求める。

(3) 崩壊土砂の乾燥密度と土粒子の密度の比で岩盤から 崩壊土砂への体積変化を考虑した崩壊岩盤量を求め, 崖鏵上部の崩壊斜面積で除して侵食量とする (式 - 2)。

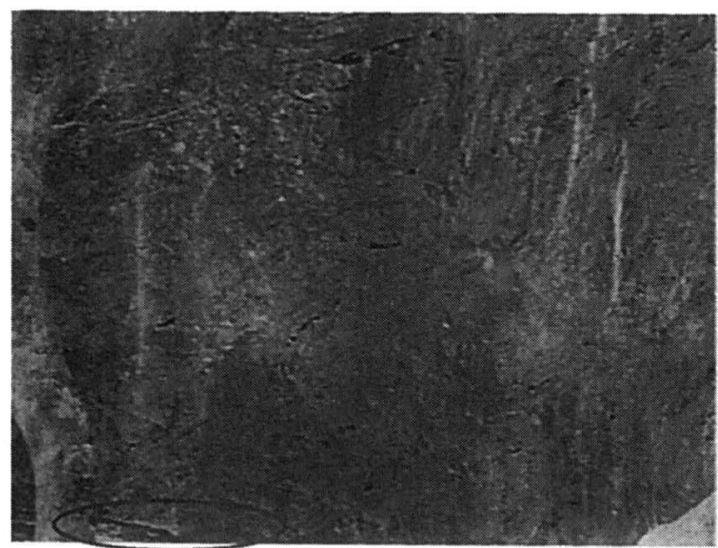

A: 1999 年 2 月 18 日

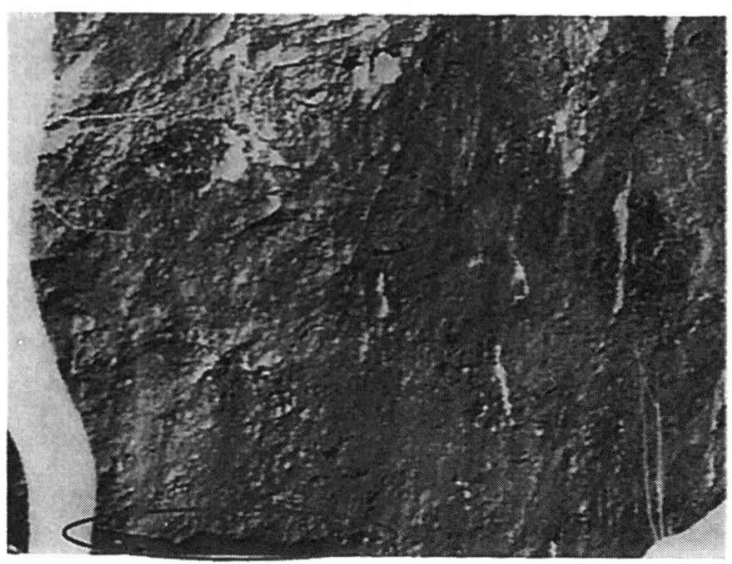

C: 1999 年 2 月 27 日

$$
d_{e}=\frac{\left(Q_{1}-Q_{2}\right) \cdot\left(\rho_{d} / \rho_{s}\right)}{A}
$$

ここで， $Q_{1} ， Q_{2}: 1998$ 年 3 月，1997年12月それぞれ の崖錘量 $\left(\mathrm{m}^{3}\right), \rho_{s}, \rho_{d}$ : 崩壊土砂の土粒子密度と乾燥 密度, $A$ : 崖鏵上部の斜面積 $\left(\mathrm{m}^{2}\right), d_{e}$ : 侵食量 $(\mathrm{m})$

その結果, $\rho_{s}=2.72 \mathrm{~g} / \mathrm{cm}^{3}, \rho_{d}=1.42 \mathrm{~g} / \mathrm{cm}^{3}$, 当該 崩壊斜面におけるこの年の冬季の平均侵食量 $d_{e}$ はおよそ $49 \mathrm{~mm}$ と見積もられる。写真 -2 Cは1998年 8 月 13 日に おける観測斜面域の広域画像で, 崖錘の形は維持されて いる。しかし, 台風による大出水後11月16日に録画した 写真- 2 Dでは崖錘は跡形もなく流出し, 崖錘のあった 痕が斜面上に僅かに認められ，河床は大きく低下した。

写真 - 3 Aは1999年 2 月18日の崩壊斜面で斜面脚部に は新たな崩落堆積物は認められない。写真 - 3 Bは1999 年 2 月 19 日の崩壊斜面で, それまで崩落による堆積物の 増加がなかった脚部に新たな崩落土の堆積が認められる。 以降 2 月 27 日（写真 -3 C）も崩落土の増加が認めら れ，4月 1 日（写真 -3 D）まで崩落が続いている。し かし, この年は前年のような大量の崩落は発生しなかっ た。

\section{2 気温変動と岩盤温度の関係}

図 -5 は2000年 1 月における観測地点の気温と岩盤温

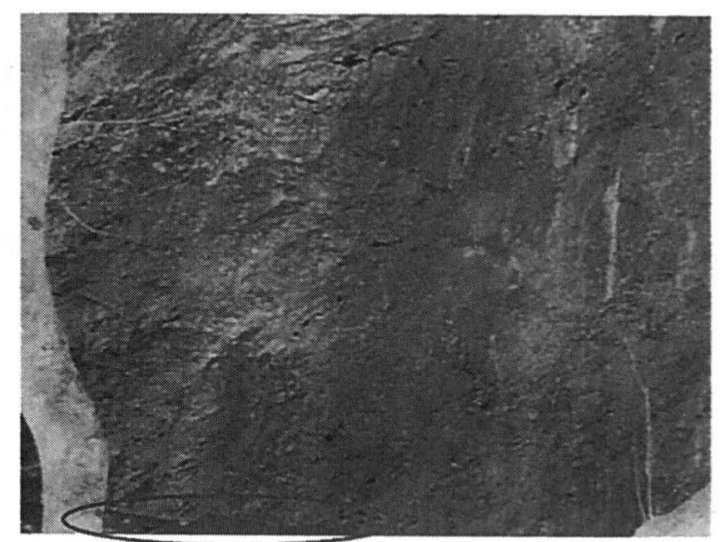

B: 1999 年 2 月 19 日

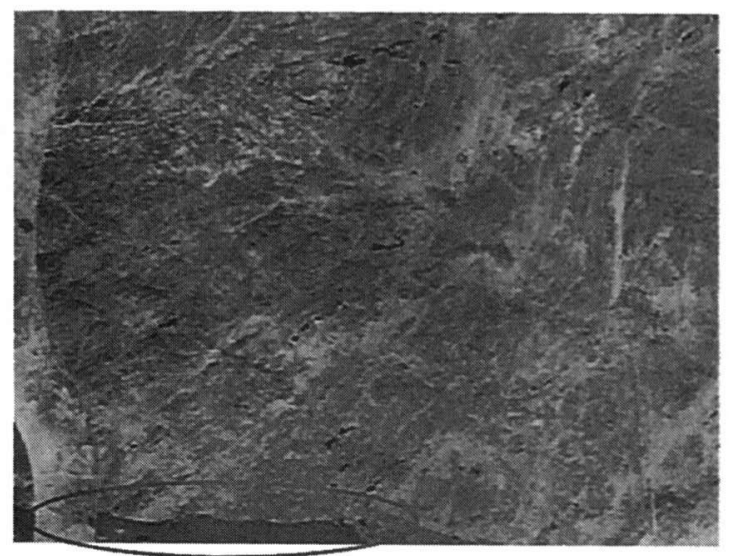

D: 1999 年 4 月 1 日

写真一 3 崩壊斜面下における崖鍾の成長

(○で示した部分は崖錘の頂部，画像は頂部の変化を見やすくするためネガ処理してある) 
度の変化を示したものである。観測地は標高770m付近 の南向き斜面で，冬季は最低気温が零下を記録する日が 多い反面，降雨，皘雪は比較的少なく日照時間が長い場 所である。観測を行ったのは図ー1，4に示すように， 崩壊斜面から $80 \mathrm{~m}$ 離れた地点の気温（百葉箱における条 件に近く，以後単に気温と呼ぶ）と崩壊斜面から $1 \mathrm{~m}$ 離 れた地点での気温（直射日光が当たらず，風通しのある 条件で観測したもので以後岩盤付近の気温と呼ぶ), 崩 壊斜面の岩盤の表面温度および表面から深さ $15 \mathrm{~cm}$ 点で の岩盤温度, および崩落斜面近くの堆積土砂直下 $50 \mathrm{~cm}$ 点の地温である。岩盤付近の気温は日照の影響を大きく 受けており，日照があれば日最高気温が出る頃には気温 との温度差が $10^{\circ} \mathrm{C}$ 近くにも達するが，夜間には気温とほ ほ同じ值になる。岩盤の温度は日照がなければ岩盤表面 の温度の方が深さ $15 \mathrm{~cm}$ 点の温度より低く, 日照を受け ると岩盤表面の温度は急激に上昇して深さ $15 \mathrm{~cm}$ 点での 温度を越え，日照のなくなる15時ごろに再び低くなる。 崩落性堆積物直下 $50 \mathrm{~cm}$ 点での地温の日変化は微小であ

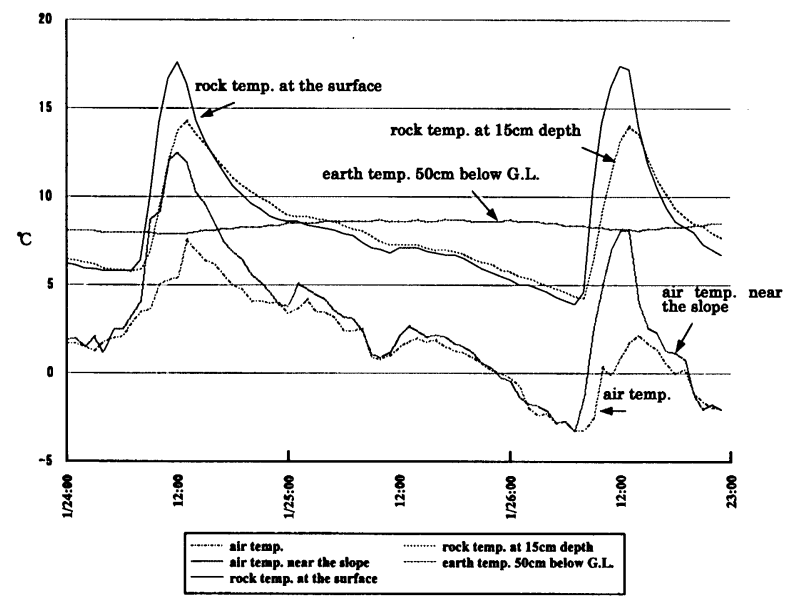

図－5＼cjkstart観測地での気温変動と岩盤の温度（Jan. 24〜26, 2000)

1 月25日は日照がなく, 日中も岩盤表面温度が15 $\mathrm{cm}$ 深での 温度を上回ることはない。

A

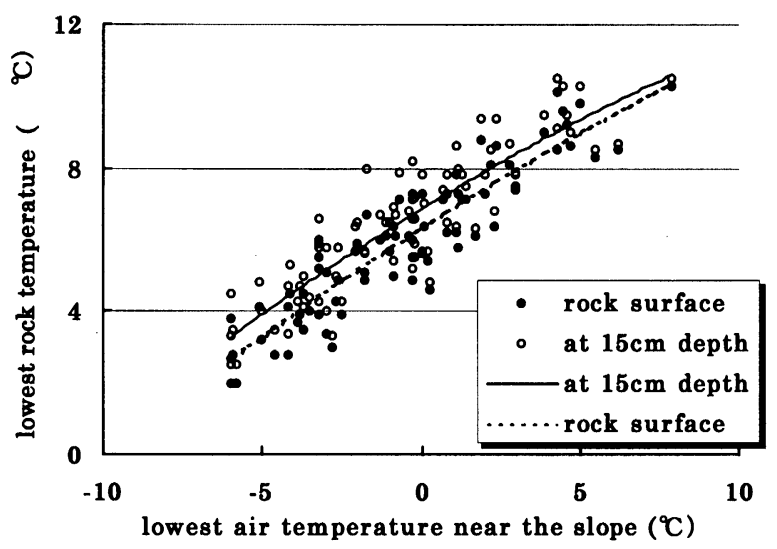

り, $7 \sim 8{ }^{\circ} \mathrm{C}$ で推移している。図- 6 は同地点での 2000 年 $1 \sim 2$ 月に記録した岩盤近くの日最低気温と同日の岩 盤の最低温度, および日最高気温と同日の岩盤の最高温 度である。最低気温 $-6{ }^{\circ} \mathrm{C}$ のきでも岩盤の表面温度は $2{ }^{\circ} \mathrm{C}$ である。岩盤の日最高温度は日最高気温と相関せず バラツキが認められるが, これは日照の有無によるもの である。

\section{3 崩落土砂の特性}

図-7 は1998年の冬季に形成された崖錘の崩落土砂の 粒径加積曲線である。崖錘を形成するマトリクス材料は 粒径 $0.3 \mathrm{~mm} \sim 3 \mathrm{~mm}$ 程度の細粒, 均等係数 $C_{u}=D_{60} / D_{10}$ $=11$, 曲率係数 $C_{u}=D_{30}{ }^{2} /\left(D_{10} \cdot D_{60}\right)=1$ で粒度分布は比較 的よい。形状は偏平で角張って抢り, 千枚岩質粘板岩が 䢃開部で剥離したもので, 凍結・融解作用によって生成 された岩屑の特性を有している (Ollier, 1971a)。一方， 崖鍾周辺に落下した大鿬は砂岩が支配的であるが, 強風 化した千枚岩質粘板岩の巨磉も数個認められた。

\section{5. 考察}

今回の測量と計算によって求められた1997年12月から 1998年 3 月までの侵食量 $49 \mathrm{~mm}$ は, 富士川砂防工事事務 所が1984年に行った調査における七面山大崩れの南向き 斜面での冬季侵食量の下限に近い值である。しかし, 凍 結・融解によって削剥された土砂が細粒であることを考 慮すれば，強風によって崖錘の外へ吹き飛ばされた土砂 もかなりの量にのぼるものと推定される。崖錘の周囲に 散らばった砂岩の大磁も含めると侵食量は計算值より大 きな值になると考えられる。

1998年12月から1999年 3 月までに伝送された崩壊斜面 の画像によれば, 崖鍾量に大きな変化はなく微量の生産 土砂量を測定することは困難だったものの，崖錘の頂部 の位置測定から崩落時期は特定された。この間の日最高 気温と最低気温を図 -8 に見ると, 最低気温が $-5{ }^{\circ} \mathrm{C}$ 以 下を記録したのは 1 月 9 日〜 14日，2月 4 日〜 7 日，お よび 2 月14日〜15日である。特に 2 月 14 日には日最低気

\section{B}

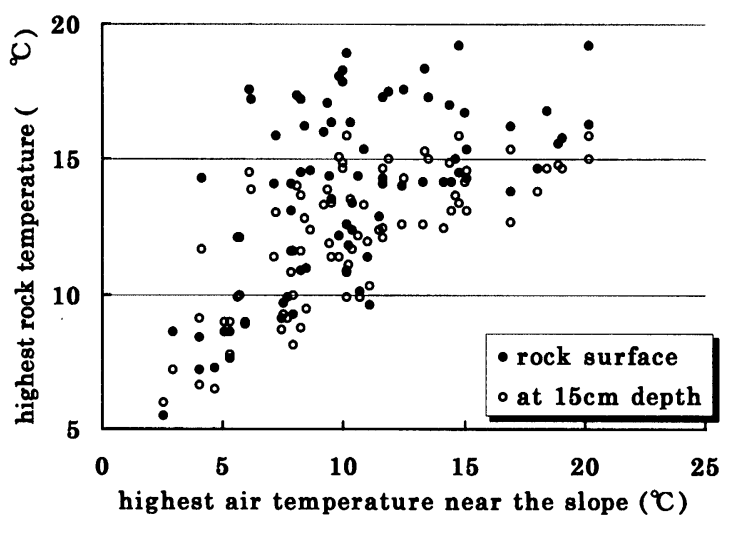

図一6 崩壊斜面付近の気温と岩盤温度の関係（Jan.〜Mar., 2000）

A：日最低気温 VS 岩盤の最低温度 B：日最高気温VS 岩盤の最高温度 
温 $-8.1^{\circ} \mathrm{C}$ を記録したが，崖錘の頂部の変化を確認でき るほど崩落を始めたのは 2 月19日である。日最高気温の 変化を見ると 2 月 18 日の $18.1^{\circ} \mathrm{C}$ が際立っており， 2 月 27 日の $19.7^{\circ} \mathrm{C}$ と続いている。日最低気温もこの頃から 2 月 22 日を除いてー $5{ }^{\circ} \mathrm{C}$ を回るようなことはなかった。崩 落は，2月18日の日最高気温 $18.1^{\circ} \mathrm{C}$ を記録した翌日， 2 月19日 (写真 -3 B) , および 2 月の最高気温を記録し た 2 月 27 日（写真 $-3 C ） に$ 顕著に発生しており, 気温 の上昇がトリガーとなって, 凍結・融解によって破砕が 進行した岩盤表面を緩ませ，その後の気温の上昇時に崩 落が発生するというメカニズムが考えられる。

今回は消費電力の関係から画像の伝送システムに JPEG方式, 圧縮率 $1 / 20$ を採用したが, 斜面の微細な変 化を解析するには不十分で, 崩落の時期の確認と平均的 な侵食量の推定にとどまった。崩落の微細な変化を定性 的, 定量的に捉えるには圧縮率を $1 / 5$ 程度に押さえるな どの対策も今後の課題である。

次に, 厳冬期の凍結・融解による岩盤表面の破砕の進 行と気温の変動を見てみる。Ollier（1971b）は凍結の 効力は, 岩盤内部の水の凍結点を上下する温度変動頻度 の関数であるとしているが，その温度変動を規制するの は水が接触している岩盤の温度であろう。観測結果では 岩盤の $15 \mathrm{~cm}$ 深における温度は, 山体内の地熱の影響を 受けており気温が $0{ }^{\circ} \mathrm{C}$ 付近のときでも気温より $6 \sim 8{ }^{\circ} \mathrm{C}$ も高い。今回は崩壊斜面の脚部, 標高770m地点で測定

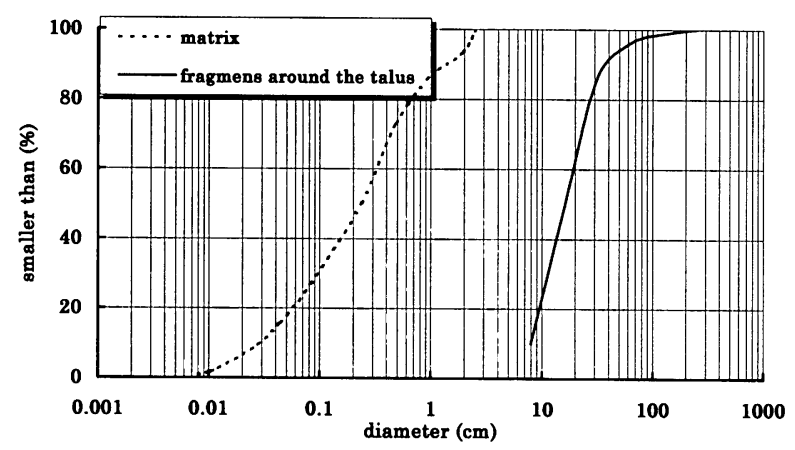

図－7 大春木沢における崩積土の粒径加積曲線

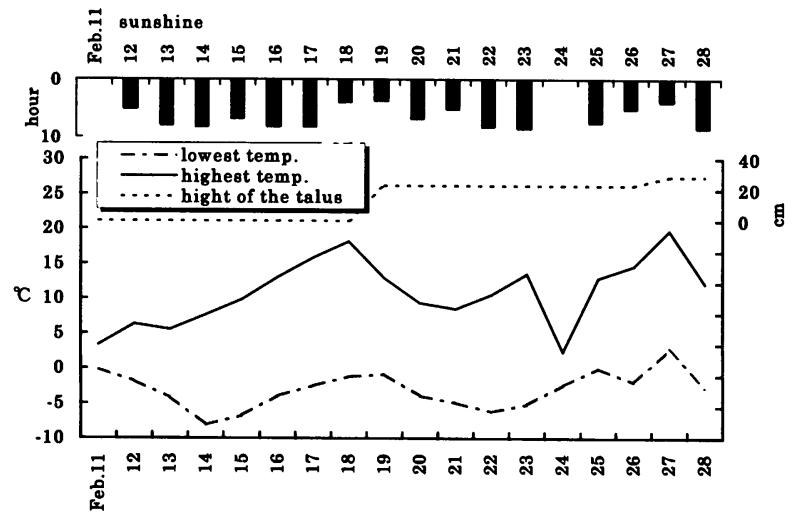

図－8 日最低・最高気温と崖錘の成長（1999年 2 月） 右軸は 2 月11日を基準とした崖錘の高さの変動量
したことや比較的温暖な冬であったこともあって，厳冬 期でも日最低気温は $-8{ }^{\circ} \mathrm{C}$ 前後, 岩盤の温度は $2{ }^{\circ} \mathrm{C}$ 程度 までしか低下しなかったが, 得られたデー夕から気温と 岩盤内部 $15 \mathrm{~cm}$ 深の温度差を $10^{\circ} \mathrm{C}$ 程度とすれば崩壊斜面 の岩盤内部の水分が凍結するには $-10^{\circ} \mathrm{C}$ 近い日最低気温 が必要になってこよう。観測斜面上部や七面山大崩れで は, 観測点より標高が高く, 岩盤温度は十分凍結点に達 していると考えられる。

次に大量に崩落した1998年と崩落の少なかった1999〜 2000年の気温について見てみる。大春木沢では長期に亘 る気温観測が実施されていないので，最も近い気象庁の 観測地点，中富における10年間（1991～2000）の気温変 動を図ー9に示す。図によると，1998年 1月の日最低気 温の平均は平年と変わらないものの, 1 月の月平均気温 は平年より $1.2^{\circ} \mathrm{C}$ 低く, 日最高気温は $2.5^{\circ} \mathrm{C}$ も低い。一方 1999年と 2000 年の 1 月は一般的に平年より暖冬傾向にあ り，1998年 1 月の低温は冬季の土砂生産に大きく寄与し たものと思われる。

\section{6. まとめと今後の課題}

冬季の崩壊斜面の変化と気温の観測によって得られた 結果は次のようである。

1）春木川流域の破砕粘板岩地带における1998年冬季の 侵食量は，49mm，もしくはそれ以上と推定される。2) 冬季の凍結・融解によって剥離した岩屑が大量に崩落を 始める条件は気温の上昇が関与していると考えられ，2月 下旬頃から崩落が顕著になってくる。3）大春木沢にお いて, 破砕粘板岩に対する凍結・融解の効力を発揮する には，気温が $-10^{\circ} \mathrm{C}$ 程度まで低下する必要がある。

以上のような解析結果は短期間の気象デー夕と 3 年間 の崩壊斜面の観測によって得られたものである。しかし， 凍結・融解による風化, 削剥の繰り返しで形成された斜 面の凹凸は崩落によって次第に平滑化し，崩落に対する 免疫性が生ずる期間も考えられ，冬季における崩落の多 塞を長期的に気温のみで予測するのは困難である。今後, 斜面の微地形の変化など継続的な観測を行うことによっ て，さらに精度のよい結果が期待できる。

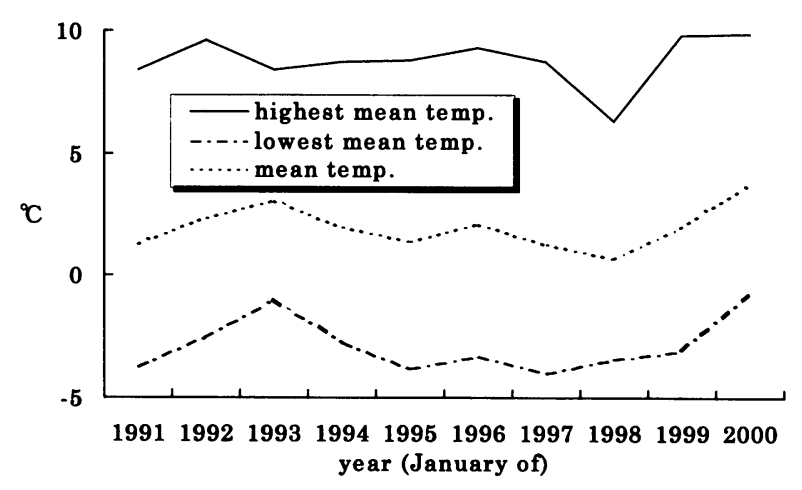

図ー9 春木川近傍, 中富における 1 月の月平均最低, 最高, および月平均気温 
また，崩壊斜面の観測に採用した画像伝送システムに ついては, 夏季における樹枝の伸長が, 落葉後もソーラー パネルを予想以上に遮蔽し，冬季の発電能力が十分に発 揮できなかったこと，低温のため想定以上にヒーターの 電力消費があったこと, 温度差による機器内の結露, 蟻 など生物の侵入による機器の不具合で欠測日がかなり あったことも改良点として報告しておく。なお，現在観 測地の大春木沢には光ケーブルを使ったカメラが 3 台設 置され，リアルタイムで現地を監視している。これらの 施設を利用すれば解像能の高い画像が得られ，より微細 な画像解析が可能となることが期待される。また，同時 に設置された大春木ダムの水位観測システムによる水文 データは画像解析とともに夏季の土石流解析にも大いに
役立つものと思われる。

\section{引用文献}

建設省関東地方建設局富士川砂防工事事務所（1985a）：七面山崩 壊推移調查報告書

建設省関東地方建設局富士川砂防工事事務所（1985b）：春木川生 産土砂量調查報告書

永井修（1998）: 七面山大崩れの歴史と崩壊の拡大, 第37回地すべ り学会研究発表講演集, 地すべり学会, pp. $485-488$

Ollier, C. D. (1971a)：風化一その理論と実態一松尾新一郎訳, 侏) ティラス, pp.15-16

Ollier, C. D. (1971b)：風化一その理論と実態一松尾新一郎訳，(㧣) ティラス, pp. $150-153$

山梨県地質図編纂委員会 (1970)：山梨県地質図 $1 / 1000,000$

（原稿受理日 平成12年 7 月 18 日） 


\section{重力性曲げ祤曲による硬質頁岩層の斜面変動}

\section{一北海道知内町尾刺建川線の例一}

「地すべり」Vol. 37 No. 4 (通巻144号) pp. 41 48, 2001年（平成13年）3月

田近 淳, 大津 直, 雨宮和夫, 和田 茂

北海道松前半島北東部の山地を開削する林道の切土法面で発生した斜面変動を記載した。この変動は, 急傾 斜の新第三紀硬質頁岩層が重力的に撓んで形成した岩盤クリープ性の曲げ褶曲が，切土による除荷によって急 速に進行した現象と考えられる。硬質頁岩層に挟まれる凝灰岩薄層と，節理に富む硬質頁岩の存在が，この斜 面変動の地質的要因である。

\section{不連続面上の光沢質黒色薄層土に起因した斜面崩壊と設計強度定数}

「地すべり」Vol. 37 No. 4 (通巻144号) pp. 49 57, 2001年（平成13年）3月 山本哲朗，鈴木素之，吉原和彦，宮内俊彦

山口県内における崩壊あるいは未崩壞合わせて 6 箇所の切取り斜面で節理面・片理面といった不連続面上に 沈殿した厚さ0.4 6.0 mmの光沢質黒色薄層土について，化学・鉱物学・物理学的性質を調へ，黒色の色彩は 非晶質で微粒子のマンガンあるいは鉄の酸化物・水酸化物によってもたらされることを明らかにした。さらに 一面せん断試験によって求められた黒色土間の平均的な内部摩擦角は $23.3^{\circ}$ ，粘着力は $7.6 \mathrm{kPa}$ であり，不連続 面上に光沢質黒色薄層土が沈殿した斜面の安定解析においてこの強度定数を設計值に用いることを提案して いる。

\section{西頸城山地付近の地すべりの特徵}

一地すべり多発地帯の地質と土質(2)-

「地すべり」Vol. 37 No. 4 (通巻144号) pp. 58 65, 2001年（平成13年）3月

岩永 伸

新潟県西頸城山地の新第三系分布地は東頸城山地とともに全国でも有数の地すべり多発地帯である。その素 因としては，で泥質岩の分布と褶曲構造，帽岩の分布などがあげられている。褶曲構造別に詳細をみると，背 斜軸付近，褶曲による逆転带，帽岩の分布するところで地すべりを発生しやすい。とくに背斜軸付近の帽岩の あるところや，背斜翼部の逆転帯で顕著である。また，地層傾斜が急なところほど地層が乱されているためか， 地すべりを頻発する傾向がある。しかし，同じ泥岩分布地の中では，岩質による地すべり発生率や発生頻度の 差はみられない。

衛星伝送画像と温度測定による崩壊斜面の侵食に関する解析

一春木川の破砕粘板岩地帯を例に一

「地すべり」Vol. 37 No. 4 (通巻144号) pp. 66 73, 2001年（平成13年）3月

永井 修, 瀬戸俊彦, 城ヶ崎正人, 中村浩之

富士川砂防工事事務所は，平成10年冬季の崩壊斜面監視のため，春木川左支大春木川に衛星電話回線を経由 した遠隔画像伝送システムを設置した。伝送された画像の解析から凍結・融解によるとみられる斜面からの崩 壊量が特定され，同時期に実施した気温，岩盤温度の観測結果から気温と崩落時期の関係が明らかになった。

\section{御荷鉾緑色岩類帯の大規模地すべり}

一蔭地すべりの変遷過程一

「地すべり」Vol. 37 No. 4 （通巻144号）pp. 74 81, 2001年（平成13年）3月

\section{夕部雅丈, 岡村 眞}

高知県大豊町の吉野川一支南小川左岸に位置する蔭地すべりは，御荷鉾帯の大規模地すべりとして知られて いる。この度調査ボーリングにより採取した炭化物より21,300年の地すべり年代を測定し，XRD結果と現地 踏査をあわせて検討した結果，当地すべりが過去 3 回の大崩壊を経たという変遷過程が明らかとなった。 